\title{
The Use of Mathcad in the Achievement of Education Students in Teaching College Algebra in a University
}

\author{
Jonathan O. Etcuban ${ }^{1 *}$, Bell S. Campanilla ${ }^{2}$, Al D. Horteza ${ }^{3}$ \\ ${ }^{1}$ Cebu Technological University, Cebu City, PHILIPPINES \\ ${ }^{2}$ University of Cebu, Cebu City, PHILIPPINES \\ ${ }^{3}$ Cebu Technological University, Cebu City, PHILIPPINES \\ *CORRESPONDENCE: $\triangle$ joetcuban@gmail.com
}

\begin{abstract}
The utilization of mathematical software offers numerous points of interest to students, which are fundamentals in the teaching-learning process in the four corners of the classroom. The study determined the effects of Mathcad as an instructional and a computational tool in teaching College Algebra to the Education students in the University of Cebu, Philippines. The study utilized a quasi-experimental using a pretest and posttest design method to 58 Education students. They are grouped by means of their final grades in high school mathematics. The study used standardized instruments such as Aiken and Dreger Revised College Algebra Attitude Scale, and Test in College Algebra by John Tobey and Jeffrey Slater. The gathered data were statistically treated using frequency, simple percentage, weighted mean, and z-test. The study revealed that the attitude towards College Algebra does not significantly affect the post-test scores of understudies in the control and test gatherings. It is inferred that instructing with the guide of media innovation isn't constantly feasible in upgrading understudies' learning in Mathematics. The researchers recommend that faculty handling mathematics should incorporate the use of mathematical software such as Mathcad in their course syllabi and the actual teaching practice.
\end{abstract}

Keywords: Mathcad, achievement, mathematics, software

\section{INTRODUCTION}

Multimedia is an important topic nowadays. The availability of low-cost sound cards and cheaper Compact Discs (CDs) drives has helped in making multimedia more accessible to home Personal Computer (PC) buyers. Multimedia PCs, at least those with CDs, are also becoming a necessity even for users in the business sector because more vendors are distributing software through CDs.

One of the latest mathematical software that is available in the computer market today is the Mathcad. This software evaluates mathematical expressions, functions, graphs, and symbolic calculations, and can solve equations from simple to complex linear and non-linear equations. Mathcad has an independent processor called SmartMath that interprets expressions as you type and determines the most efficient way for Mathcad to evaluate them.

Ordinarily, Mathcad evaluates an expression correctly as you type in it (Maxfield, 2013; Porter \& Hill, 1996). It does so even if a bit of simplification would have made the expression much more comfortable to evaluate (Margueron et al., 2010). When SmartMath is on you can tell Mathcad to try and simplify an expression (Fitch, 1993). Make sure SmartMath is turn on and type the keyword "optimize" above the

Article History: Received 10 January $2019 \bullet$ Revised 15 January $2019 \bullet$ Accepted 17 January 2019

(C) 2019 by the authors; licensee Modestum Ltd., UK. Open Access terms of the Creative Commons Attribution 4.0 International License (http://creativecommons.org/licenses/by/4.0/) apply. The license permits unrestricted use, distribution, and reproduction in any medium, on the condition that users give exact credit to the original author(s) and the source, provide a link to the Creative Commons license, and indicate if they made any changes. 
assignment statement containing the expression to simplify. If Mathcad finds a simpler form, it marks the expression with a red asterisk (Liengme, 2015). To see the simplified form of the expression, double-click on the asterisk. Mathcad uses this simpler form in all subsequent calculations (Benker, 2012; Guiñón et al., 2007). To make Mathcad optimize all assignments without your having typed "optimize" before each one, choose SmartMath Controls from the Math menu, pull right and choose Optimize. Mathcad will optimize all assignments statements.

Because of this fast pacing technology, mathematics instructors may utilize this software as an instructional and computational tool in teaching Mathematics, specifically College Algebra, in the undergraduate programs. Teachers should update their strategies and methodologies in teaching Mathematics for the growth and welfare of the students (Boekaerts \& Corno, 2005; Llinares \& Krainer, 2006; Zakaria et al., 2010).

Students who enroll in the College of Teacher Education ought to be given able guidelines, adequate instructional media, and satisfactory school hardware and offices to encourage them become mentally capable in the quest for knowledge. They should be enhanced with techniques and methods on how to handle subjects using the latest technology as an instructional tool. By providing them with sufficient instructional media and teaching the right techniques and methods, teachers, through Mathcad, can help students in acquiring knowledge, and themselves in becoming better teachers. According to Etcuban and Pantinople (2018) that teachers are at the forefront of every learning institution. They teach and nurture the minds of students.

The Commission of Higher Education (CHED) has implemented the use of Information Technology (IT) as part of the curriculum in all private and public Higher Education Institutions (HEIs) in the Philippines. The use of the latest mathematical tool in teaching Mathematics in school would give advantages in teaching and a change in the trend of handling Mathematics, specifically, College Algebra.

The purpose of this study is to know the effects of using Mathcad as an instructional and computational tool in teaching College Algebra in the second year Education students. It aims to show that Mathcad would be a great help in acquiring knowledge in Mathematics in general and College Algebra in particular. Moreover, it tries to answer these questions: Is it significant as an instructional and computational tool in teaching Mathematics? Can this be endorsed to all colleges and universities as far as instructional media is concerned?

\section{FRAMEWORK}

The study is anchored on Self-Efficacy Theory (SET), Social Cognitive Theory (SCT), and Cognitive Load Theory (CLT).

Self-efficacy is the faith in one's capacity to impact occasions that influence one's life and command over the manner in which these occasions are experienced (Bandura, 1993). It has a noteworthy influence in deciding our odds for progress; in reality a few therapists rate self-adequacy above ability in the formula for progress (Multon et al., 1991; Pajares \& Schunk, 2001). We have to give careful consideration to self-viability when defining objectives to ensure that man's adequacy convictions are in accordance with its points and not neutralizing them (Schunk, 1995).

The fundamental idea in SCT is that a person's activities and responses, including social practices and intellectual procedures, in pretty much every circumstance are impacted by the activities that individual has seen in others (Bandura, 2014; Porter et al., 2003). The hypothesis expresses that when individuals watch a model playing out a conduct and the outcomes of that conduct, they recall the grouping of occasions and utilize this data to direct consequent practices (Kelder et al., 2015). Watching a model can likewise incite the watcher to take part in conduct they officially learned (Stahl et al., 2006). At the end of the day, individuals do not learn new practices exclusively by attempting them and either succeeding or bombing, but instead, the survival of mankind is needy upon the replication of the activities of others (Bandura, 2014). Contingent upon whether individuals are compensated or rebuffed for their conduct and the result of the conduct, the onlooker may reproduce conduct demonstrated (Strauss, 2017; O'Fallon \& Butterfield, 2012). Media gives models to a huge swath of individuals in a wide range of natural settings (Wilson \& Myers, 2000).

The CLT proposes that learning happens best under conditions that are lined up with human intellectual engineering (Paas et al., 2004). The structure of human subjective design, while not known definitely, is recognizable through the consequences of test examine (Jones et al., 2009). It has been intended to give rules proposed to aid the introduction of data in a way that empowers student exercises that upgrade scholarly execution (Valcke, 2002). Sweller's hypothesis utilizes parts of data handling hypothesis to stress the 
characteristic constraints of simultaneous working memory stack on picking up amid guidance (Van Gog et al., 2005). It makes utilization of the composition as essential unit of examination for the plan of instructional materials (Kirschner, 2002).

Multimedia will change the way people use their computers. As the power of the PCs catches up man's ability to dream, create and inform, the introduction of mathematical software will have a different impact in the teaching of Mathematics specifically College Algebra.

Interactive multimedia is not a product. It is a massive march of applied technologies that span the range of computer tasks. Desktop video and multimedia will touch no area in the computer industry. Offers economical alternatives to conventional methods through sound and video that are remarkably useful tools, offering easy user-interaction and, entirely just, fun. There is a line that connects education to entertainment, and it is multimedia that helps cross that line.

Teaching models are based on theories of how students learn (Ramsden, 2003). The teacher must, therefore, list down steps toward attaining the desired learning outcomes (Kumaravadivelu, 2001). Effective teachers have learned to use a variety of teaching techniques to allow students to acquire what they want to learn since teachers now recognize that students learn differently (Darling-Hammond, 2008). According to Etcuban (2013), the integration of science and innovation into instructional practices has made another road in adopting new ideal models in educating students. The accessibility of tremendous data in the Internet and the innovative headway help educators in the conveyance of exercises making it agreeable. Some students learn by watching, listening, and inquiring; others learn best by a group or social interactions, and still, others need special personal attention in order to learn. Again, it is emphasized that the more teaching skills and strategies a teacher have at his command, the higher is the chance for more students to achieve the desired learning outcomes.

The computer revolution is at hand. A computer is a tool, which may have multiple uses in the mathematics classroom. It may be a device for making the learning of concepts, skills, and problem solving more effective than that of traditional practice. Computer-assisted instruction reveals that students get a variety of responses by way of animation, graphics, and audio. Among areas surveyed that are beneficial to instruction are computer learning in Mathematics, computational skills, basic reading skills, and general education. Recent researches show that computer learning lends itself to positive attitudes towards learning, such as by way of increased motivation and improved self-esteem among learners.

One way to adapt and capitalize the technological advances is to organize thinking on the use of media in the teaching-learning process. Another will be to test the effectiveness of the latest technologies in the crucible of the classroom and the context of particular learning situations. However, no matter how the teacher today adapts himself to his new role, it becomes clear that the modern teacher has been provided with new opportunities to exercise his unique personal capabilities and to face the challenge of the technological age.

The studies above clearly showed that the use of computers could be beneficial not only to the students who need sufficient instructional media but also to the teachers for them to grow professionally in their practice. When properly trained, students tend to increase their computational skills in College Algebra thus, mathematical software such as Mathcad assists educators in enhancing students' learning.

The researchers gained more insights into the teaching of Mathematics using technology by going over the previous studies. However, his study differed in the following aspects: Mathcad was adapted as a computational and instructional tool in teaching the subject, instead of Mathematica, Geometer's Sketchpad, and any other mathematical software available in the computer market. Mathcad was used only in some selected topics in College Algebra.

\section{OBJECTIVES OF THE STUDY}

This study identified the effects of Mathcad as an instructional and a computational tool in teaching College Algebra to the Education students in the University of Cebu, Philippines. Specifically, the study aimed to answer the: 1) Profile of the participants who enrolled in College Algebra, in terms of their age, sex, and average final Mathematics grade in High School in the control and experimental groups; 2) Students' attitudes towards College Algebra, achievement in College Algebra in both groups; 3) Students' performance in College Algebra; and 4) Significant difference between the attitudes towards College Algebra and the mean gained from pre-test and post-test scores of both groups. 
Table 1. Distribution of Research Participants

\begin{tabular}{|c|c|c|c|c|c|c|c|c|}
\hline \multirow{3}{*}{ Course } & \multicolumn{4}{|c|}{ Control Group } & \multicolumn{4}{|c|}{ Experiment Group } \\
\hline & \multicolumn{2}{|c|}{ Male } & \multicolumn{2}{|c|}{ Female } & \multicolumn{2}{|c|}{ Male } & \multicolumn{2}{|c|}{ Female } \\
\hline & $\mathbf{f}$ & $\%$ & $\mathbf{f}$ & $\%$ & $\mathbf{f}$ & $\%$ & $\mathbf{f}$ & $\%$ \\
\hline BSED & 5 & 38.46 & 7 & 43.75 & 2 & 22.22 & 1 & 5.00 \\
\hline BEED & 8 & 61.54 & 9 & 56.25 & 7 & 77.78 & 19 & 95.00 \\
\hline Total & 13 & 100.00 & 16 & 100.00 & 9 & 100.00 & 20 & 100.00 \\
\hline
\end{tabular}

\section{METHODOLOGY}

In this study, the experimental method of research was used. The experimental lasted for two weeks from June 10 - 24, 2018. The researchers did careful observation and measurement of results. The administration of pre-test in College Algebra to both groups was given last June 10, 2018, and the post-test on June 24, 2018. Time accuracy of each test was one hour and thirty minutes.

This experimental study made use of the group design using two groups as its subjects: the control and the experimental groups. The research respondents were divided into two groups according to Average Final Mathematics Grade in High School. To make the two groups comparable, the researchers arranged their grade from highest to lowest, then randomly assigned the respondents either to control group or experimental group. The control group received teaching methodologies and techniques without the aid of Mathcad as an instructional and computational tool, while the experimental group utilized Mathcad as an instructional and computational tool in addition to the usual teaching methodologies and techniques received by the control group.

The said groups were given precisely the same set of the course outline and class activities. Such activities included classroom exercises, board work, examinations, assignments, and discussions. The two groups were given a standardized test in College Algebra to find out the performance of the students, which was evaluated through the scores acquired. This examination was used to determine whether or not the instructional and computational tool, which was the Mathcad, has a significant effect on the learning process.

The control group was given the methods of teaching as follows: class discussions and problem illustration, evaluation of students' learning through written examinations, seatwork, board work, and assignments for further study and computations. In the experimental group, the method of teaching was the same as the control group. However, there were times during discussions that the teacher used Mathcad as an instructional and computational tool in teaching and solving problems in College Algebra. Students asked questions on how to manipulate the mathematical software.

Data were collected, tabulated, analyzed, and interpreted from the given attitudinal and standardized tests in College Algebra. A comparison was then made based on the results obtained by the two groups. Remedial measures were then proposed to improve students' performance and learning outcomes in College Algebra based on the experimental study.

The study conducted at the University of Cebu Main Campus, College of Teacher Education. The University is located in the heart of Cebu City, Philippines.

There were 58 participants consisted of 15 Bachelor in Secondary Education (BSED) and 43 Bachelor in Elementary Education (BEED) students. Each participant has already taken Basic Mathematics as a prerequisite to the College Algebra course. Most of them have attended their second course in public schools. Further description of the two groups is summarized in Table 1.

The researchers used three-sets of instruments. The first instrument used is Form 138-A (Scholastic Record Form) of students. This was used to get the students' average final mathematics grade in high school. The second instrument is the standardized Aiken and Dreger Revised College Algebra Attitude Scale. This was used to determine the attitudes of the students towards the subject. The students using the five-point scale accomplished the test: 5 points for Strongly Agree, 4 points for Agree, 3 points for Undecided or Not Sure, 2 points for Disagree, and 1 point for Strongly Disagree. The third instrument is the Standardized Test in College Algebra by John Tobey and Jeffrey Slater. This was used to measure the achievement of the students in College Algebra and to determine whether or not mathematical software had a significant effect on the learning process. 
Table 2. Profile of the Participants in College Algebra

\begin{tabular}{|c|c|c|c|c|}
\hline & \multicolumn{2}{|c|}{$\begin{array}{c}\text { Control Group } \\
(\mathrm{n}=29)\end{array}$} & \multicolumn{2}{|c|}{$\begin{array}{c}\text { Experimental Group } \\
(n=29)\end{array}$} \\
\hline & $\mathbf{f}$ & $\%$ & $\mathbf{f}$ & $\%$ \\
\hline \multicolumn{5}{|l|}{ Age (in years) } \\
\hline $24-27$ & 1 & 3.45 & 1 & 3.45 \\
\hline $20-23$ & 11 & 37.93 & 6 & 20.69 \\
\hline $16-19$ & 17 & 58.62 & 22 & 75.86 \\
\hline \multicolumn{5}{|l|}{ Sex } \\
\hline Male & 13 & 44.83 & 9 & 31.03 \\
\hline Female & 16 & 55.17 & 20 & 68.97 \\
\hline \multicolumn{5}{|l|}{ Grade } \\
\hline $95-100$ (Excellent) & 1 & 3.45 & & \\
\hline $90-94$ (Very Good) & 3 & 10.34 & 3 & 10.34 \\
\hline $80-89$ (Good) & 19 & 65.52 & 19 & 65.52 \\
\hline $76-79$ (Fair) & 5 & 17.24 & 6 & 20.69 \\
\hline 75 (Passing) & 1 & 3.45 & 1 & 3.45 \\
\hline
\end{tabular}

The second year Educations students in the control and the experimental groups were used as the participants of this experimental study. The same teacher in College Algebra handled both groups. The following procedures were done to gather data. First, the researchers conducted a Standardized Pre-test in College Algebra to the two groups. Then, they gave to the experimental group discussions and hands-on tutorials on Mathcad as an instructional and computational tool teaching and solving some selected topics in College Algebra. In the control group, some selected topics in College Algebra that make use of the traditional and usual teaching methods were discussed. Then, the researchers gave a Standardized Post-test in College Algebra to both groups. Next, the researchers evaluated students' attitude towards College Algebra in both control and experimental groups. The data were collected, tabulated, analyzed, and interpreted using frequency, simple percentage, weighted mean, and z-test. The study assumed that the population means are equal.

\section{RESULTS AND DISCUSSIONS}

Evaluation is an intricate process. Before it is finalized, data must be gathered, presented and studied. After the critical analysis of the data, they are interpreted. From the interpretation, one could perceive the outcomes, whether the venture succeeded or failed.

\section{Profile of the Participants}

The profile of the participants under this experimental study consists of age, sex, and average final mathematics grade in high school, attitudinal test, and their pre-test and post-test scores from the standardized College Algebra test.

Table 2 shows that only 1 or $3.45 \%$ belonged to the age bracket of 24 to 27 of both groups. The age bracket of 20 to 23 of the control and experimental groups got 11 and 6 respectively. While the age bracket of 16 to 19 got the highest distribution score of 17 and 22 for both groups. From the data above, it can be implied that respondents in both groups are equivalent regarding age levels. Most of them fall on the same age category which means respondents can be classified as teenagers.

Also, the table presents that there were 13 males and 16 females that belonged to the control group. The experimental group had 9 males and 20 females. Furthermore, the table presents that there were more female students enrolled in College Algebra than male students. It can be said that there were more female respondents than male respondents than male respondents in both groups. This implies that there are more female students enrolled in College Algebra than male students.

The table presents that most of the respondents in both control and experimental groups fell under the category Good, which grade range from 80 to 89 . Furthermore, the table shows that both groups are comparable. It is assumed that the indication used in this study can affect the learning capabilities of the students, specifically College Algebra. It implies that both groups were equivalent and comparable regarding average final mathematics grade in high school. This implies that majority of the learners in College Algebra were average as to analytical capabilities. 
Table 3. Distribution of Students' Attitudes in College Algebra

\begin{tabular}{cccccc}
\hline \multirow{2}{*}{ Raw Score } & Description & \multicolumn{2}{c}{$\begin{array}{c}\text { Control Group } \\
(\mathbf{n = 2 9 )}\end{array}$} & $\begin{array}{c}\text { Experimental Group } \\
(\mathbf{n}=\mathbf{2 9})\end{array}$ \\
\cline { 3 - 5 } & & $\mathbf{f}$ & $\mathbf{\%}$ & $\mathbf{f}$ & $\mathbf{\%}$ \\
\hline $189-225$ & Strongly Agree & 0 & 0.00 & 0 & 0.00 \\
\hline $153-188$ & Agree & 7 & 24.14 & 9 & 31.03 \\
\hline $117-152$ & Undecided & 18 & 62.07 & 17 & 58.62 \\
\hline $81-116$ & Disagree & 4 & 13.79 & 3 & 10.34 \\
\hline $45-80$ & Strongly Disagree & 0 & 0.00 & 0 & 0.00 \\
\hline
\end{tabular}

Table 4. Distribution of Students' Performance in College Algebra

\begin{tabular}{|c|c|c|c|c|c|c|c|c|c|}
\hline \multirow{3}{*}{ Grade } & \multirow{3}{*}{ Description } & \multicolumn{4}{|c|}{$\begin{array}{c}\text { Control Group } \\
(\mathrm{n}=29)\end{array}$} & \multicolumn{4}{|c|}{$\begin{array}{c}\text { Experimental Group } \\
(\mathrm{n}=29)\end{array}$} \\
\hline & & \multicolumn{2}{|c|}{ Pre-test } & \multicolumn{2}{|c|}{ Post-test } & \multicolumn{2}{|c|}{ Pre-test } & \multicolumn{2}{|c|}{ Post-test } \\
\hline & & $\mathbf{f}$ & $\%$ & $\mathbf{f}$ & $\%$ & $\mathbf{f}$ & $\%$ & $\mathbf{f}$ & $\%$ \\
\hline $16-20$ & Excellent & & & 2 & 6.90 & 1 & 3.45 & 4 & 13.79 \\
\hline $12-15$ & Very Proficient & 3 & 10.34 & 6 & 20.69 & 2 & 6.90 & 2 & 6.90 \\
\hline $8-11$ & Proficient & 2 & 6.90 & 8 & 27.59 & 2 & 6.90 & 3 & 10.34 \\
\hline $4-7$ & Less Proficient & 2 & 6.90 & 3 & 10.34 & 3 & 10.34 & 11 & 37.93 \\
\hline $0-3$ & Poor & 22 & 75.86 & 10 & 34.48 & 21 & 72.41 & 9 & 31.04 \\
\hline
\end{tabular}

\section{Students' Attitudes in College Algebra}

Table 3 shows that no one in the control and experimental groups could strongly agree, nor strongly disagree with the indicators given in the attitudinal test. Most of the respondents were undecided, or they were not sure with the statements found in the said test.

Based on the table, it can be said that respondents both in control and experimental groups were seemingly equivalent and comparable with each other, as to students' attitude in College Algebra. Furthermore, it implies that the majority of the respondents were undecided or they were not sure with the statements found on the attitudinal test.

According to Domino (2009) that teachers influenced students' understanding and attitudes toward mathematics through the way that they taught mathematics, by making certain that their students understood mathematics, and through their personalities. In particular, students claimed that they understood and liked mathematics when their teachers had fun and interesting lessons, had the students actively engaged in the classroom, showed the students how the mathematics that they were learning was related to their lives, taught at a relatively slow pace, helped students outside of the classroom thought about there lessons, and were eager about mathematics. Students claimed that they did not understand and disliked mathematics when their teachers had boring monotonous lessons, did not have the students actively involved in the classroom, did not show students the relevance and importance of learning mathematics, taught at a rapid pace, did not encourage student questions in the classroom, were not available to help students outside of the classroom, did not seem to care about their students, and showed no enthusiasm about teaching mathematics.

Small (2002) says that College Algebra blocks the scholastic chances and plans for roughly 200,000 understudies for every semester. Members concurred that we ought not to acknowledge this imperative of human potential. Essential, in any case, is the way that few enhanced College Algebra programs have prevailing with regards to bringing down disappointment grades while turning around the negative demeanors of students towards mathematics.

\section{Students' Performance in College Algebra}

Table 4 presents the results of students' performance in College Algebra.

Table 4 reveals that the pre-test scores obtained by the respondents of both groups were very low. The data imply that there is a need for improving students' mathematical skills. More practice drills, examples, homework, as well as board work, are needed to help sharpen analytical capabilities of the learners. Furthermore, the table shows the increasing results of the post-test scores of the control group. It implies that there is an increase in learning among the students of the control group in College Algebra. 
Table 5. Pre-test and Post- Comparisons of Students' Attitudes towards College Algebra

\begin{tabular}{lcccccccc}
\hline \multicolumn{8}{c}{ Mean } & \multicolumn{2}{c}{ StDev } \\
\hline Group & Pre-test & Post-test & Pre-test & Post-test & z value & cv at 0.05 & Significance & Result \\
\hline Control & 3.00 & 7.79 & 3.88 & 5.33 & 3.91 & 1.67 & Significant & Ho rejected \\
\hline Experimental & 3.21 & 7.00 & 4.63 & 5.48 & 2.84 & 1.67 & Significant & Ho rejected \\
\hline
\end{tabular}

On the other hand, in the experimental group, the pre-test results were more likely the same as that of the control group. However, during the post-test examination, students in the control group gained more than the experimental group. Thus, it means that Mathcad did not satisfactorily contribute and enhance students' learning, specifically in College Algebra. The table also implies that respondents in the experimental group were not ready in the use of computers as a tool in learning Mathematics. Learning Mathematics at the same time learning computers was difficult for them to adjust. They were cyberphobic since it was the first time they used computers.

College Algebra is a required, center course for some sciences and arithmetic majors in different universities. The course had the most minimal passing rate of any class on grounds. The organization communicated an unmistakable goal to enhance this high disappointment rate and gave assets to achieve this reason. The investigation of Wynegar and Fenster (2009) demonstrated that the customary address conveyance framework had the most astounding evaluation point normal and one of the least falling flat rates of teaching strategies.

The study of Hauk et al. (2015) revealed no significant differences in College Algebra achievement gain by homework group, when statistically controlling for previous mathematics achievement. Results support the conjecture that web-based homework is at least as effective as traditionally graded paper-and-pencil homework for understudies learning College Algebra in tolerably estimated address-based classes.

\section{Significance of Data}

The study hypothesized that the attitude of the students towards the course in the control and experimental groups does not affect the post-test scores. Secondly, it was also hypothesized that the attitudes towards College Algebra of both groups are not significantly related. Lastly, there is no significant difference between post-test scores of the control and experimental groups.

Table 5 presents the relationship of two groups in contrast to the attitudes of the students towards College Algebra.

The table shows the statistical comparison of both groups on post-test scores. The results indicate the rejection of the null hypothesis, which says that the attitude towards College Algebra does not significantly affect the post-test scores of students in the control and experimental groups. The computed value of $\mathrm{z}$ is higher than the critical value of 1.67 at 0.05 level of significance of the df of 29 . Based on the data on the table, it implies that teaching mathematics through the use of Mathcad, significantly affect student's achievement in College Algebra.

The discoveries of the investigation of Gallo and Odu (2009) recommend that albeit numerous students may lean toward escalated courses or packed timetables that limit the time they spend on grounds, these planning choices may not be ideal for learning, in any event not in science.

The study of Isiksal and Askar (20005) suggests that students showed great enthusiasm for a mathematical software. Students in the experimental group had the highest scores compared to other groups regarding mathematics achievement and mathematics self-efficacy.

Taylor (2008) conducted a study on mathematics anxiety and attitudes toward mathematics. It determined if the technology course lowered mathematics anxiety, as well as improved attitudes. The findings of found that students executed and additionally the control group taught by lecture. The anxiety of the experimental group diminished more than the control gathering, and the trial gathering's demeanor toward mathematics enhanced at a more prominent rate than the control group.

The investigation of Hodges and Kim (2013) was directed to explore the adequacy of a treatment intended to enhance College Algebra students toward mathematics. Factually noteworthy outcomes were watched for enhanced mentalities toward mathematics.

Table 6 presents the relationship between the students' attitude in College Algebra of the control and experimental groups. 
Table 6. Comparison of Mean Scores of Student's Attitude of Both Groups

\begin{tabular}{lccccccc}
\hline Group & Mean & StDev & z Value & cv at 0.05 & df & Significance & Result \\
\hline Control & 136.93 & 22.95 & \multirow{2}{*}{1.29} & \multirow{2}{*}{1.67} & \multirow{2}{*}{56} & \multirow{2}{*}{ Not Significant } & \multirow{2}{*}{ Ho accepted } \\
\cline { 1 - 5 } Experimental & 143.97 & 18.39 & & & & &
\end{tabular}

Table 7. Comparison of the Post-test Mean Scores of the Control and Experimental Groups

\begin{tabular}{lccccccc}
\hline Group & Mean & StDev & z Value & cv at 0.05 & df & Significance & Result \\
\hline Control & 7.79 & 5.33 & 0.56 & \multirow{2}{*}{1.671} & 56 & \multirow{2}{*}{ Not Significant } & Ho accepted \\
Experimental & 7.00 & 5.48 & & & & & \\
\hline
\end{tabular}

The table reveals that the attitudinal mean of the experimental group is higher than the attitudinal mean of the control group. Furthermore, the $\mathrm{z}$ value of 1.29 is less than the critical value of 1.67 at 0.05 level of significance of the df of 56. This implies the acceptance of the null hypothesis, which says that the attitudes towards College Algebra of the control and experimental groups do not significantly differ.

Table 7 shows that the control group gained more than the experimental group in the post-test scores. The data mean that there is no significant difference between the post-test means of both groups.

A closer look at this table, however, would show that the post-test mean of the control group was numerically higher than the post-test mean of the experimental group. This implies that the mathematical software, which is the Mathcad, did not significantly affect students' learning in the experimental group.

The hypothesis was tested at the standard table of 0.05 level of significance. The computed $\mathrm{z}$ of the posttest scores of both groups was less than its critical value of 1.67. Thus, the null hypothesis was accepted. This means that the post-test scores of the two groups do not significantly differ.

As an analysis, therefore, the researchers will dare say that teaching Mathematics with the aid of computers sometimes may not at all help achieve learning situations in the classroom. The experimental group in this study did not perform better than the control group because respondents in the experimental group were cyberphobic and math phobic. The respondents in both groups do not have computer classes during their high school years. It is therefore essential to go deeper into the underlying concept of Mathematics. Teachers should emphasize the use of deductive proof and develop the tool of logic and reasoning. Adjust the pace and content of Mathematics to the rapid expansion that is taking place in scientific knowledge. Teachers should likewise encourage students to respond to learning situations using their ideas, and select instructional materials for teaching that provide appropriate stimuli for learning tasks.

The researchers believe that the locale of the study, the family background and social status of the students affect the learning achievement in the course. The respondents of the study find it challenging to adapt multimedia software because of the common factors that computer classes were not offered during the respondent's high school days.

Administrators should carefully evaluate whether or not a particular mathematical software positively enhances students' learning, and is relevant to the formulation of knowledge. They must give full support to the teaching staff for the implementation of multimedia software in teaching Mathematics.

The teachers can prepare and organize ways and techniques needed in their practice. It is necessary to look into the possible causes of students' low achievement in Mathematics, specifically College Algebra. Study habits, learning difficulties, and family background must also be taken into consideration.

Another revelation that the study exposed is the positive relationship between students' attitudes in College Algebra and the post-test scores. Guided by these facts, guidance counselors, teachers, as well as the parents concerned, should see to it that these aspects must be taken into account if only to improve students' behavior and performance in Mathematics, specifically College Algebra in its mathematical analysis and computations. Furthermore, the study found out the student' attitude contributes to the academic achievement in Mathematics.

\section{CONCLUSIONS}

The study concluded that the use of Mathcad as an instructional and computational tools in College Algebra has no critical impacts on the learners' accomplishment. Given quality education, however, school administrators should enforce and include the use of computers in all aspects of the curricular program. It is the great responsibility of the educators to help students especially in the College of Education to become 
mentally competent in their teaching practice. The implementation of the use of computers would give a different impact in teaching Mathematics if properly handled by the teachers and administrators. It is not only the concern of CHED to monitor the course program offered by the HEIs, but it is also the concern of the tertiary institutions to re-engineer and revise curricula if needed. It is also concluded that teaching with the aid of multimedia technology is not always viable in enhancing students' learning in Mathematics.

\section{RECOMMENDATIONS}

The researchers strongly recommend that mathematics teachers should incorporate mathematical software such as Mathcad in their course syllabi and the actual teaching practice. Also, it is recommended that mathematics teachers should scholarly assist students in their activities to help build good foundations and concepts in Mathematics.

\section{Disclosure statement}

No potential conflict of interest was reported by the authors.

\section{Notes on contributors}

Jonathan O. Etcuban - Doctor of Philosophy in Technology Management, Doctor of Philosophy in Education Management, Faculty, College of Teacher Education, Cebu Technological University, Cebu City, Philippines.

Bell S. Campanilla - Candidant, Doctor of Philosophy in Technology Management, Faculty, College of Computer Studies, University of Cebu, Cebu City, Philippines.

Al D. Horteza - Doctor of Philosophy in Technology Management, Faculty, College of Information and Communication Technology, Cebu Technological University, Cebu City, Philippines.

\section{REFERENCES}

Bandura, A. (2014). Social cognitive theory of moral thought and action. In Handbook of moral behavior and development (pp. 69-128). Psychology Press. Retrieved from https://goo.g1/j2EWA7

Bandura, A. (1993). Perceived self-efficacy in cognitive development and functioning. Educational psychologist, 28(2), 117-148. https://doi.org/10.1207/s15326985ep2802_3

Benker, H. (2012). Practical use of Mathcad®: Solving mathematical problems with a computer Algebra system. Springer Science \& Business Media. Retrieved from https://goo.gl/P57iwu

Boekaerts, M., \& Corno, L. (2005). Self-regulation in the classroom: A perspective on assessment and intervention. Applied Psychology, 54(2), 199-231. https://doi.org/10.1111/j.1464-0597.2005.00205.x

Darling-Hammond, L. (2008). Teacher learning that supports student learning. Teaching for intelligence, 2(1), 91-100. Retrieved from https://goo.gl/XQpCiZ

Domino, J. (2009). Teachers' influences on students' attitudes toward mathematics. Research and Teaching in Developmental Education, 32-54. Retrieved from https://goo.g1/6MErKz

Etcuban, J. O. (2013). Professional and ICT efficacy plan of instructors based on their training needs at the University of Cebu Campuses, Philippines. IAMURE International Journal of Multidisciplinary Research, 5(1), 1-1. https://doi.org/10.7718/iamure.v5i1.617

Etcuban, J. O., \& Pantinople, L. D. (2018). The effects of mobile application in teaching high school mathematics. International Electronic Journal of Mathematics Education, 13(3), 249-259. https://doi.org/10.12973/iejme/3906

Fitch, J. (1993). Mathematics goes automatic. Physics world, 6(6), 48. https://doi.org/10.1088/2058-7058/6/6/23

Gallo, M. A., \& Odu, M. (2009). Examining the relationship between class scheduling and student achievement in College Algebra. Community College Review, 36(4), 299-325. https://doi.org/10.1177/0091552108330902

Guiñón, J. L., Ortega, E., García-Antón, J., \& Pérez-Herranz, V. (2007). Moving average and Savitzki-Golay smoothing filters using Mathcad. Papers ICEE, 2007. Retrieved from https://goo.gl/Djq11n 
Hauk, S., Powers, R. A., \& Segalla, A. (2015). A comparison of web-based and paper-and-pencil homework on student performance in College Algebra. Primus, 25(1), https://doi.org/10.1080/10511970.2014.906006

Hodges, C. B., \& Kim, C. (2013). Improving college students' attitudes toward mathematics. TechTrends, 57(4), 59-66. https://doi.org/10.1007/s11528-013-0679-4

Isiksal, M., \& Askar, P. (2005). The effect of spreadsheet and dynamic geometry software on the achievement and self-efficacy of 7th-grade students. Educational Research, 47(3), 333-350. https://doi.org/10.1080/00131880500287815

Jones, B. D., Baumgartner, F. R., Breunig, C., Wlezien, C., Soroka, S., Foucault, M., ... \& Mortensen, P. B. (2009). A general empirical law of public budgets: A comparative analysis. American Journal of Political Science, 53(4), 855-873. https://doi.org/10.1111/j.1540-5907.2009.00405.x

Kelder, S. H., Hoelscher, D., \& Perry, C. L. (2015). How individuals, environments, and health behaviors interact. Health behavior: Theory, research, and practice, 159. Retrieved from https://goo.gl/ypXGM5

Kirschner, P. A. (2002). Cognitive load theory: Implications of cognitive load theory on the design of learning. https://doi.org/10.1016/S0959-4752(01)00014-7

Kumaravadivelu, B. (2001). Toward a postmethod pedagogy. TESOL quarterly, 35(4), 537-560. https://doi.org/10.2307/3588427

Liengme, B. V. (2015). An overview of SMath Suite. In SMath for Physics. Morgan \& Claypool Publishers. Retrieved from https://goo.gl/278ets

Llinares, S., \& Krainer, K. (2006). Mathematics (student) teachers and teacher educators as learners. Handbook of research on the psychology of mathematics education: Past, present and future, 429-459. Retrieved from https://goo.gl/nmR216

Margueron, X., Besri, A., Jeannin, P. O., Keradec, J. P., \& Parent, G. (2010). Complete analytical calculation of static leakage parameters: A step toward HF transformer optimization. IEEE Transactions on Industry Applications, 46(3), 1055-1063. https://doi.org/10.1109/TIA.2010.2045327

Maxfield, B. (2013). Essential PTC ${ }^{\circledR}$ Mathcad Prime ${ }^{\circledR}$ 3.0: A guide for new and current users. Academic Press. Retrieved from https://goo.gl/LEnYJw

Multon, K. D., Brown, S. D., \& Lent, R. W. (1991). Relation of self-efficacy beliefs to academic outcomes: A meta-analytic investigation. Journal of counseling psychology, 38(1), 30. https://doi.org/10.1037/00220167.38.1.30

O'Fallon, M. J., \& Butterfield, K. D. (2012). The influence of unethical peer behavior on observers' unethical behavior: A social cognitive perspective. Journal of Business Ethics, 109(2), 117-131. https://doi.org/10.1007/s10551-011-1111-7

Paas, F., Renkl, A., \& Sweller, J. (2004). Cognitive load theory: Instructional implications of the interaction between information structures and cognitive architecture. Instructional science, 32(1-2), 1-8. https://doi.org/10.1023/B:TRUC.0000021806.17516.d0

Pajares, F., \& Schunk, D. H. (2001). Self-beliefs and school success: Self-efficacy, self-concept, and school achievement. Perception, 11, 239-266. Retrieved from https:/goo.gl/CV1ctm

Porter, L. W., Bigley, G. A., \& Steers, R. M. (2003). Motivation and work behavior. Retrieved from https://goo.gl/uFpvFY

Porter, G. J., \& Hill, D. R. (1996). Interactive Linear Algebra: A laboratory course using Mathcad (TM). Springer Science \& Business Media. Retrieved from https://goo.gl/41Pxiz

Ramsden, P. (2003). Learning to teach in higher education. Routledge. https://doi.org/10.4324/9780203507711

Schunk, D. H. (1995). Self-efficacy and education and instruction. In Self-efficacy, adaptation, and adjustment (pp. 281-303). Springer, Boston, MA. https://doi.org/10.1007/978-1-4419-6868-5_10

Small, D. (2002). An urgent call to improve traditional college algebra programs. Focus: The newsletter of the Mathematical Association of America, May-June, 12-13. Retrieved from https://goo.gl/8QB1pb

Stahl, G., Koschmann, T. D., \& Suthers, D. D. (2006). Computer-supported collaborative learning. na. Retrieved from http://gerrystahl.net/hci/chls.pdf

Strauss, A. L. (2017). Psychological modeling: Conflicting theories. Routledge. https://doi.org/10.4324/9781315127644 
Taylor, J. M. (2008). The effects of a computerized-algebra program on mathematics achievement of college and university freshmen enrolled in a developmental mathematics course. Journal of College Reading and Learning, 39(1), 35-53. https://doi.org/10.1080/10790195.2008.10850311

Valcke, M. (2002). Cognitive load: updating the theory?. Learning and Instruction, 12(1), 147-154. https://doi.org/10.1016/S0959-4752(01)00022-6

Van Gog, T., Ericsson, K. A., Rikers, R. M., \& Paas, F. (2005). Instructional design for advanced learners: Establishing connections between the theoretical frameworks of cognitive load and deliberate practice. Educational Technology Research and Development, 53(3), 73-81. https://doi.org/10.1007/BF02504799

Wilson, B. G., \& Myers, K. M. (2000). Situated cognition in theoretical and practical context. Theoretical foundations of learning environments, 57-88. Retrieved from https://goo.gl/Y182dt

Wynegar, R. G., \& Fenster, M. J. (2009). Evaluation of alternative delivery systems on academic performance in College Algebra. College Student Journal, 43(1). Retrieved from https://goo.gl/2rNMx5

Zakaria, E., Chin, L. C., \& Daud, M. Y. (2010). The effects of cooperative learning on students' mathematics achievement and attitude towards mathematics. Journal of social sciences, 6(2), 272-275. https://doi.org/10.3844/jssp.2010.272.275 